Health \& Medicine | Nikhitha Mantri

\section{Is monoclonal antibody therapy effective and achievable in hospitals with limited resources?}

\begin{tabular}{|c|c|c|}
\hline $\begin{array}{l}\text { Monoclonal antibody therapy } \\
\text { (MAT) is a way of treating } \\
\text { COVID-19 for people who } \\
\text { have tested positive, have mild } \\
\text { to moderate symptoms, and } \\
\text { are at high risk of developing } \\
\text { more serious symptoms and } \\
\text { complications. Although there } \\
\text { are already studies showing } \\
\text { promising results, the number } \\
\text { of patients in the US, especially } \\
\text { ethnic minorities, who have } \\
\text { so far received MAT is small. } \\
\text { Dr Nikhitha Mantri along } \\
\text { with a team of researchers } \\
\text { at BronxCare Health System, } \\
\text { conducted a study with the aim } \\
\text { of examining the advantages } \\
\text { and the practicality of MAT } \\
\text { in an inner-city hospital with } \\
\text { limited resources. }\end{array}$ & $\begin{array}{l}\text { he ongoing global pandemic of } \\
\text { COVID-19 disease is caused by the } \\
\text { severe acute respiratory syndrome } \\
\text { coronavirus } 2 \text { (SARS-CoV-2). As of January } \\
2022, \text { the pandemic has caused more } \\
\text { than } 307 \text { million cases and } 5.49 \text { million } \\
\text { deaths, making it one of the deadliest } \\
\text { in history. The fact that the disease has } \\
\text { been shown to affect ethnic minorities } \\
\text { disproportionately has amplified the need } \\
\text { to focus on their individual characteristics } \\
\text { and treatment requirements. } \\
\text { Ethnic minorities in the US and } \\
\text { elsewhere in the world show higher } \\
\text { rates of infections, hospitalisations, and } \\
\text { deaths. As compared to Caucasians, } \\
\text { African Americans have a } 1.1 \times \text { higher } \\
\text { rate of infection, 2.8x higher rate of } \\
\text { hospitalisation, and 1.9x higher death } \\
\text { rate. Hispanics, on the other hand, have } \\
\text { a } 2 \times \text { higher rate of infection, 3x higher } \\
\text { rate of hospitalisation and } 2.3 x \text { higher } \\
\text { death rate compared to Caucasians. } \\
\text { The area of the Bronx in New York } \\
\text { has a Hispanic population of } 56 \% \text { in } \\
\text { a community that is predominantly }\end{array}$ & $\begin{array}{l}\text { served by the BronxCare Health System, } \\
\text { making the need to evaluate the COVID- } \\
19 \text {-focused care offered in this area } \\
\text { highly important. } \\
\text { A recent study by the US Centres for } \\
\text { Disease Control and Prevention (CDC) } \\
\text { showed there is a racial and ethnic } \\
\text { disparity in the receipt of medications } \\
\text { for treatment of COVID-19. The study } \\
\text { showed that Black and Hispanic patients } \\
\text { received lower rates of monoclonal } \\
\text { antibody therapy as compared to the } \\
\text { white population. This ongoing study } \\
\text { involving nearly } 100 \text { patients included } \\
\text { mostly ethnic minority populations, } \\
\text { as the hospital primarily caters } \\
\text { healthcare to the under-served and } \\
\text { minority population. } \\
\text { MONOCLONAL } \\
\text { ANTIBODY THERAPY } \\
\text { The most recently approved treatments } \\
\text { for COVID-19 in the US, the UK, and other } \\
\text { parts of the world include antiviral pills } \\
\text { (such as Molnupiravir and Paxlovid) and } \\
\text { monoclonal antibody therapy (MAT). MAT } \\
\text { is a way of treating the disease for people } \\
\text { who have tested positive for COVID-19, } \\
\text { have mild symptoms, and are at high } \\
\text { risk of developing serious complications. } \\
\text { Monoclonal antibodies are antibodies } \\
\text { (proteins used by the immune system to } \\
\text { identify and neutralise foreign objects } \\
\text { such as bacteria and viruses) made } \\
\text { in the laboratory by cloning a unique } \\
\text { white blood cell. They have so far been } \\
\text { used in medicine to treat a number of } \\
\text { diseases such as a variety of cancers and } \\
\text { autoimmune adieases (diseases caased by }\end{array}$ \\
\hline
\end{tabular}
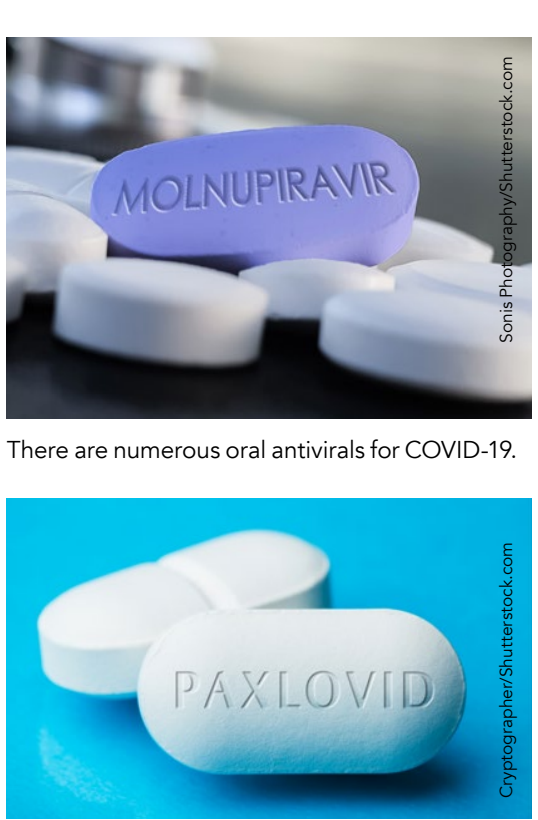

MAT can be used alongside antivirals.

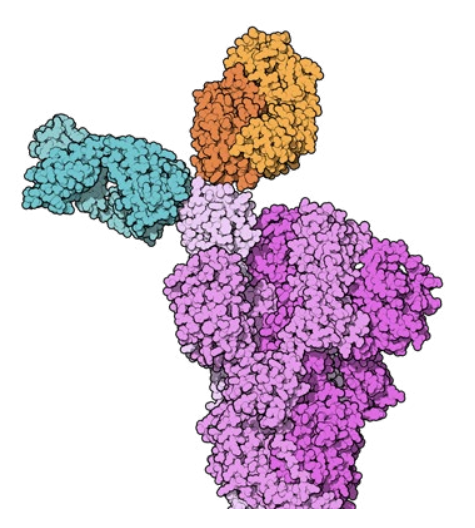

Structure of SARS-COV-2 spike protein.

an abnormal immune response against a part of the human body.

With COVID-19, the monoclonal antibodies target the receptor binding spike protein. This protein is used by the virus to attach itself to the host ells (cells lining the upper and bow airways) by binding itself to special cell receptors called angiotensin-converting enzyme 2 (ACE2) receptors.

One of the treatments capable of binding to the virus RBD and blocking viral entry into the host cells is

Bamlanivimab (also knowns as LY-CoV555 or LY3819253). The United States Food and Drug Administration (FDA) issued an emergency use authorisation (EUA) This EUA has Bamlanivmab in 2021. This EUA has recently been revoked for Bamlanivimab monotherapy due to the

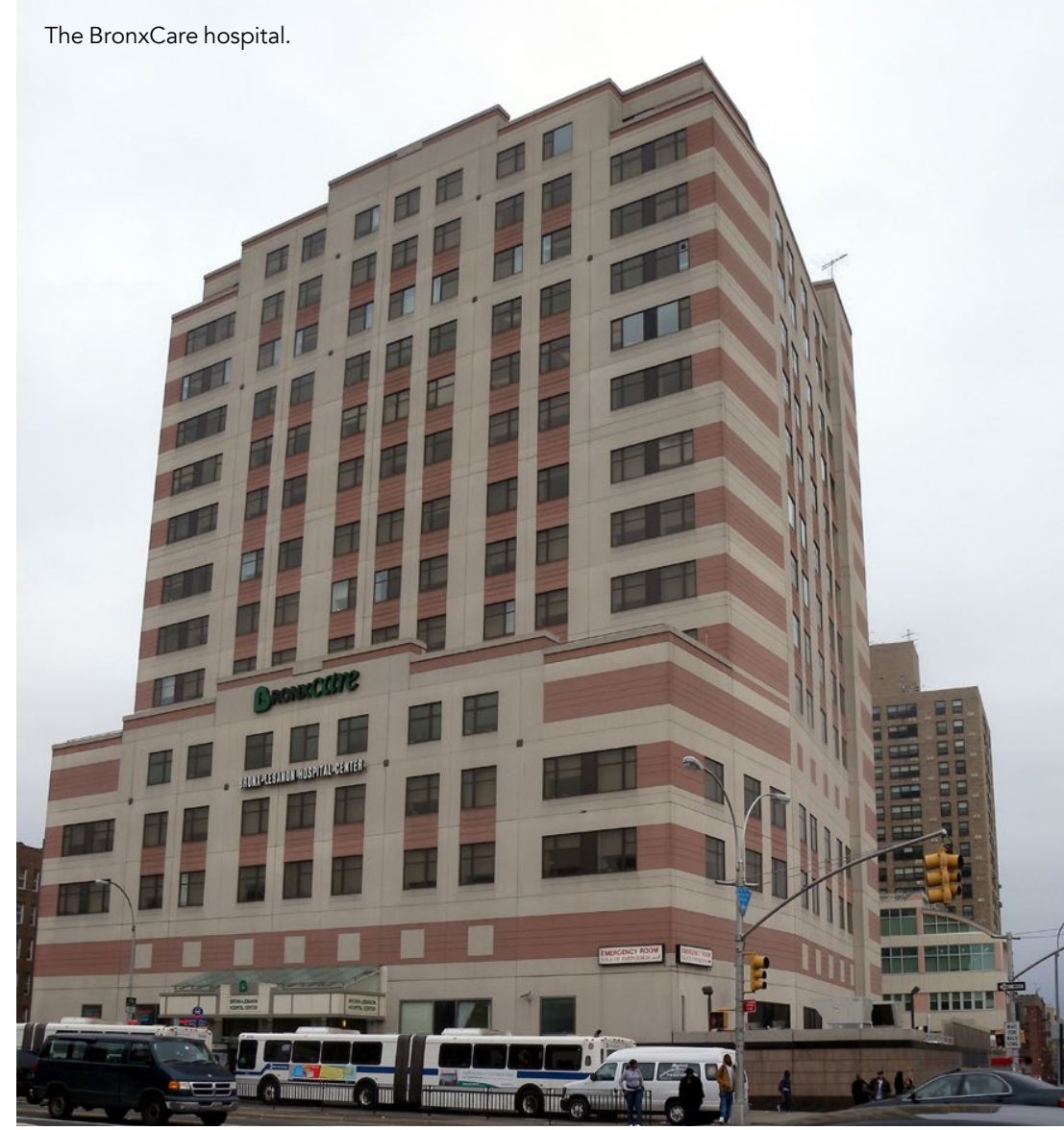

The study showed benefits from the MAT when it came to patient deaths and admissions to hospital.

the FDA recently approved the use of a combined treatment of newly available Im tevimab (CASIMD), CrasivimabEteserima (CASIMD), Or Bamlanivinaof MAT in mild to moderate COVID-19 demonstrated promising outcomes in preventing progression to severe disease in patients with high risk factors and consequently led to fewer hospital visits and admissions.

\section{THE BRONXCARE}

STUDY CHALLENGE

In order to examine the efficiency and the practicality of MAT in a hospital with limited resources such as the BronxCare Health System, Dr Nikhitha Mantri and Dr Sridhar Chilimuri led a retrospective observational study involving 49 adult patients who were diagnosed with mild 272020 to MOVh 172021 . Nhovember 27 2020 to 19 rch 17 2021. The diagnosis real-time reverse transcriptase polymeras CoV-2 on nasophanngeal swabs.

Patients who were included in the study had to present with symptoms of less from one or more high-risk conditions for progression to severe disease. The criteria for high-risk of disease included body mass index (BMI) greater than or equal to $35 \mathrm{~kg} / \mathrm{m}^{2}$, chronic kidney disease, diabetes, immunosuppressive disease, current immunosuppressive treatments, or the patient being 65 years of age or older. High-risk groups also included patients over 55 years of age with heart disease, high blood pressure, or long term respiratory disease. Patients who required admission to the hospital with severe disease, patients requiring oxygen, and pasentswith hreasing termgen requirements who were on longthan ten days duration, and had to suffer 


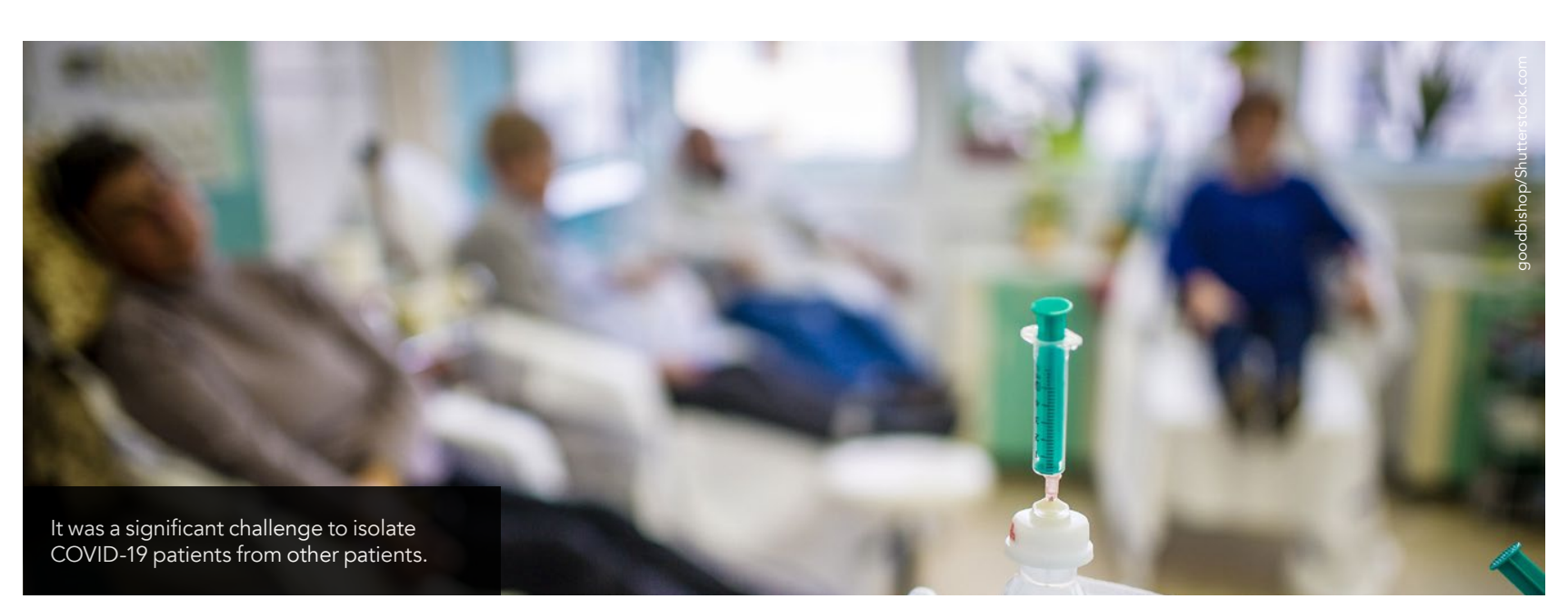

were excluded from the study. Out of these 49 patients, 38 received MAT treatment and 11 declined MAT. Whe treatment group, 16 received the received the CAS-IMD therapy (1200 $200 \mathrm{mg}$ since both BAM and CAS IMD fusions had been in use at that time based on availability Patients with mild to moderate disease with risk factors, who were offered a MAT infusion but denied, served as a control group.

Identifying extra space isolated from other non-COVID-19 patients was a significant challenge in the hospital, since is a traditional infusion centre and had many immunocompromised patients who were being treated at the same time for their individual diseases. Despite the Imited resources, a comprehensive and successful mons

and 65 years respectively, with both groups having more female than $\mathrm{ma}$ were Hispanics (60.5\%) followed by Were Hispanics (60.5\%) followed by (10.5\%) Amercans (23.7\%), Caucasians in both groups were on average ovenweight, while high blood pressure and diabetes were the most common isk factors in both groups.

The two different types of MAT treatments used in the study had similar results. Unfortunately, the data obtained for the control group was restricted to hospitalisations and deaths, however it was adequate to suggest a significant reduction in COVD-19 related hospitalisation and deaths for the patien that had the treatment. In addition, the majority of patients (76.3\%) reported early appearance of BAM-resistant strains, the study results cannot be used to promote a treatment consisting only of DAM. The curent standard treatment is BAM and ETE, or CAS a IMD. The study performed by Mantri and the team at BronxCare showed the beneft of MAT treatments when it comes to patient deaths and admissions to hospital for their predominantly Hispanic patients with a high burden of risk. It seems an early administration of MAT may have influenced this favourable outcome. Nearly 100 patients have been treated in their health system, including those with autoimmune diseases and immunosuppressed patients. The team feels there is still work to be done to more accurately define the characteristics Hispanic population of the US. programme was created by a

doctors and other

healthcare workers.

The team feels there is still work to The new challenge The team'sinitial benefits of MAT in minority Hispanic and with the new variants focus was also on the education of African American populations in the US. of SARS-CoV-2,

fast-track emergency room physicians.

Data on demographics, co-morbidities, Woratory test results, and medication were obtained from electronic medica records. All patients were followed up for 30 days via telephone appointments

MAT IS EFFECTIVE

and CAS-IMD groups were 70 years

similar to previous studies' results. It is perhaps worth noting that three of the 38 patients treated with the infusion presented later (eight to nine days) after the symptoms' onset. This potentially means that a delay in MAT administration atter COVID-19 symptom onset may

ARE CURRENT MATS

In light of the recent revocation of BAM

as a treatment on its own due to the specifically demonstrates mutations on the spike protein RBD of the virus, potentially causing the existing MATs to struggle to work against it. The next step, besides the development of a more effective vaccine against the strain than those currently available, would most likely be to test the efficacy of existing MAT in patients affected with the novel Onicron strain, and potentially work on the development of new and more antigen-specific
antibody treatments.

\section{Research Objectives}

Dr Nikhitha Mantri at the BronxCare Health System studied Dre advant

\section{Detail}

\section{Address}

作 Bronx, New York 19457, USA

Nikhitha Mantri was born in Visakhapatnam, India. She completed her MBBS at SDM Medical College India. She then pursued residency in internal medicine and is currently doing her fellowship in gastroenterology at BronxCare Health System,

Collaborators

Dr Sridhar Chilimuri, Dr Haozhe Sun, Ms Karnokjun Annie Youthjug, Dr Maleeha Zahid, Dr Sudharsan Gongati, Dr Suresh Kumar Nayudu, DrMadanmohan Patel, Dr Giovan Franchin, Dr Diana Ronderos, Dr Angel De La Cruz, Dr Hesh Gujar, Dr Pavana Wranasi, Dr Haider Ghazanfar, Dr

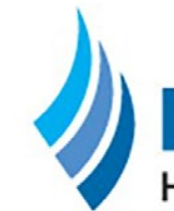

BronxCare HEALTH SYSTEM

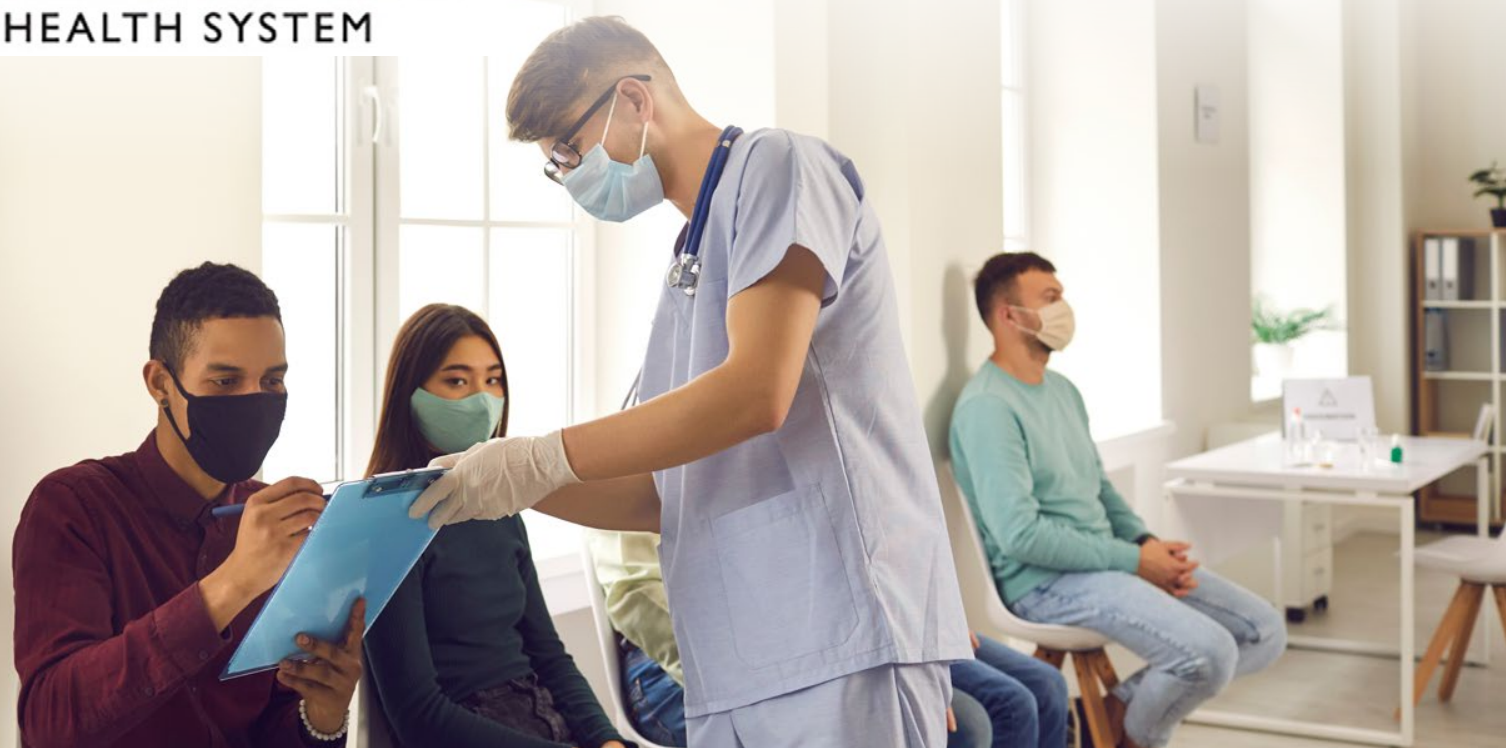

\section{References}

Chilimuri, S, Mantri, N, Gurjar, Het al (2021) Implementation and outcomes of monoclonal antbody infusion for COVD-19 Journal of the National Medical Association, 11, 54. doi. org/10.1016/.jinma.2021.08.036

Pogue, JM, Lauring, AS, Gandhi, TN et al (2021) Monoclonal Antibodies for Early Treatment of COVID-19 in a World of Infectious Diseases. doi.org/10.1093/ofid/ofab268. Zuo, L, et al, Ao, G, Wang Y, et al (2021) Bamlanivimab improves hospitalization and mortality rates in patients with Infection, 23, 20. doi.org/10.1016/jijinf.2021.09.003
.

\section{Personal Response}

Is your team planning to conduct a bigger and more detailed study in order to assess the

II Yes. Our team is expanding the study using the newer monoclonal antibodies like Bamlanivimab-Etesevimab variant due to tect present, we are unable to test for the to provide the necessary treatment including monoclonal antibodies administration to patients. We are planning publishing the outcomes shortly. 